\title{
Standardization of in vitro Multiplication Protocol for Picrorhiza kurroa (Royle Ex. Benth)
}

\author{
Surjeet Singh Bisht ${ }^{1^{*}}$ and Sanjeev Verma ${ }^{2}$
}

${ }^{1}$ Plant Tissue Culture Laboratory, Department of Molecular Biology and Biotechnology, College of Horticulture, VCSG UUHF Bharsar, Pauri-246123, Uttarakhand, India

${ }^{2}$ Department of Food Science and Technology, College of Horticulture, VCSG UUHF Bharsar, Pauri-246123, Uttarakhand, India

*Corresponding author

\section{A B S T R A C T}

Keywords

Picrorhiza kurroa, Callusing, Shooting, Rooting, Organogenesis

Article Info

Accepted:

15 July 2019

Available Online:

10 August 2019
An in vitro protocol for plant regeneration through organogenesis was established for Picrorhiza kurroa Royle Ex. Benth (Scrophulairaceae). The plant is a principle source of glycoside that is Picroside-I, Picroside-II and Kutkoside. Callus was induced on Murashige and Skoog basal medium supplemented with cytokinin (Kn or BA) and auxin (2,4-D/IBA/NAA) using leaf, petiole and stem explants. Shoots were regenerated on MS media with BA (1.5 to $2.5 \mathrm{mgl}^{-1}$ ) combined with auxin (IBA or NAA) in the range of 0.5 to $2.5 \mathrm{mgl}^{-1}$. Rooting was initiated with full or half media supplemented with 0.5 to $1.5 \mathrm{mgl}^{-1}$ of IBA or NAA. In vitro regenerated plantlets were successfully transferred to the soil. Pots having garden soil with organic compost and regular irrigation of half strength MS solution at initial stages are desirable for higher survival of plantlets.

\section{Introduction}

Picrorhiza kurroa Royle ex. Benth commonly known as Kutki, is an important temperate medicinal plant species found in western Himalayas, a fast depleting medicinal value plant belonging to family Scrophulairaceae. It is perennial herb and also the principle source of glycoside that is Picroside-I, Picroside-II and Kutkoside which are extracted from dried rhizomes and roots of 3 year old plants (Rastogii et al., 1949, Jia et al., 1999). Other identified active constituents are apocynin, drosin, and nine cucurbitacin glycosides (Weinges et al., 1972, Stuppner and Wagner 1989).

It is extensively used in both modern as well as traditional systems of medicine for its invaluable medicinal properties being stomachic, cathartic, cholagogue, blood purifier and useful in treating jaundice, asthma, flatulence, cardiac complaints, antifungal and chronic hepatitis as its active 
constituents are apocynin, drosin, and nine cucurbitacin glycosides (Weinges et al., 1972, Stuppner and Wagner 1989 and Hussain 1984). Now a day's researches are more focused on evaluating its hepatoprotective, anticholestic antioxidant and immune modulating activity (Atal et al., 1986, Subedi 2000). In the past few decades there has been a resurgence of interest in the study and use of medicinal plants in health care and in recognition of the importance plants to the health system (Hoareau and DaSilva 1999).

The natural resurgence of Picrorhiza kurroa is through rhizomes and seeds, however their cultivation rate is very poor. The poor cultivation coupled with over exploitation for pharmaceutical use has depleted the species from natural habitat. The Indian system of medicine is predominantly dependent upon the use of plant based raw materials in most of their preparations and formulations, thereby, widening the gap between demand and supply and thus, putting further pressure on the species. In fact $P$. kurroa is now listed at one of the endangered plant species of India (Nayar and Shastry, 1990).

Owing to these factors, the species is at the verge of extinction. It is essential for the conservation of $P$. kurroa to encourage ex-situ plantation which require large scale planting material. In view of the problems of conventional propagation and high demand of planting material, the large scale multiplication of this species can only be met efficiently and economically in a sort span of time by in vitro propagation. Therefore, an efficient in vitro propagation system for producing this plant is required to further clarify its potential medicinal values and germplasm conservation. Plant regeneration from $P$. kurroa has earlier been reported using shoot tips (Nanda and Ahuja 1996). Our finding are at variance from the earlier report in tissue culture of this species.

\section{Materials and Methods}

Picrorhiza kurroa leaf, petiole and stem explants collected from the Division of Medicinal and Aromatic Plants Block College of Horticulture VCSG, UUHF, Bharsar, Pauri Garhwal, India. Initially the plant materials were washed with tap water followed by washing with $1 \%(\mathrm{v} / \mathrm{v})$ labolene detergent for 15 minutes and then in running tap water for 30 minutes. The explants were surface sterilized with an aqueous solution of $0.1 \%$ $\mathrm{HgCl}_{2}$ (w/v) for 2-3 minute. The explants are then rinsed several times with sterilized double distilled water. Damage parts were aseptically trimmed with sterilized surgical blade. All the explants were separately inoculated in the MS basal medium (Murashige and Skoog, 1962) supplemented with growth regulators such as cytokinin ( $\mathrm{Kn}$ or BA) and auxin (2,4-D/IBA/NAA). Coconut Milk (CM), incorporated into basal medium in varying concentrations. The $\mathrm{pH}$ of the media was adjusted to $5.8 \pm 0.1$ using $0.1 \mathrm{NaOH}$ or $0.1 \mathrm{HCL}$. The medium was autoclaved at 1.06 $\mathrm{kg} \mathrm{cm}{ }^{2}$ at $121^{0} \mathrm{C}$ for 25 to 30 minutes. Cultures were incubated at $24^{\circ} \mathrm{C} \pm 2{ }^{\circ} \mathrm{C}$ and $60 \%$ relative humidity with 16: 8 hours light and dark photoperiod.

To induce root formation, regenerated shoots were transferred to MS medium supplemented with full or half strength mineral salts and different concentrations of auxins (0.5 to 1.5 $\mathrm{mgl}^{-1}$ IBA or NAA). Rooted plantlets were transferred to thermocol cups having (1) sterilized mixture of soil and organic compost manure in the ratio of $1: 1(\mathrm{v} / \mathrm{v}),(2)$ sterilized mixture of sand and soil in the ratio of $1: 1$ (v/v), (3) sterilized forest soil. The thermocol cups were kept in the Growth chamber at $18^{\circ} \mathrm{C}$ $\pm 2^{0} \mathrm{C}$ temperature and $60 \%$ relative humidity with 16:8 hours light: dark photoperiod. Plantlets were transferred to earthenware pots containing different soil types. They were transferred in shade for two weeks and 
watered regularly. All the potted plants were then transferred to sun gradually increasing the periodicity of exposure.

\section{Results and Discussion}

Callusing response in the form of callus biomass was measured at the interval of 25 days up to 100 days using leaf, petiole and stem explants (Table 1). MS medium was supplemented with cytokinin (Kn or BA) and auxin (2,4-D/IBA/NAA) in varying concentration and combinations. $15 \mathrm{~m} / \mathrm{l} \mathrm{CM}$ was added with $2,4-\mathrm{D}\left(1.5-2.0 \mathrm{mg} / \mathrm{l}^{-1}\right)$ and cytokinin $\left(0.5-1.5 \mathrm{mg} / \mathrm{l}^{-1}\right)$ in another set of experiment. MS medium without any cytokinin and auxin failed to induce callusing in all the explants. Highest callus biomass (fresh weight) was recorded in 2.0: $2.5 \mathrm{mg} / \mathrm{l}^{-1}$ of $\mathrm{Kn}$ : 2,4-D combination for leaf and 2.5 $\mathrm{mg} / \mathrm{l}^{-1} \mathrm{Kn}$ with $3.0 \mathrm{mg} / \mathrm{l}^{-1}$ 2,4-D as well as 3.0 $\mathrm{mg} / \mathrm{l}^{-1} \mathrm{Kn}$ with $2.5 \mathrm{mg} / \mathrm{l}^{-1} 2,4-\mathrm{D}$ for stem explants (Plate 1 and 3 ).

BA: IBA $\left(1.5 \mathrm{mg} / \mathrm{l}^{-1:} 2.0 \mathrm{mg} / \mathrm{l}^{-1}\right)$ combination produced maximum callus biomass in petiole explants (Table 1 and Plate 2). Second highest values were recoded in 2.5: $2.5 \mathrm{mg} / \mathrm{l}^{-1}(\mathrm{Kn}$ : 2,4-D) combination in leaf and stem, 2.0: 2.0 $\mathrm{mg} / \mathrm{l}^{-1}$ (BA: IBA) and 1.0: $1.5+\mathrm{CM}$ (BA: 2,4D) combination in petiole explants. $\mathrm{Kn}$ and 2,4-D combination induced better calli in leaf and stem explants than BA with other auxin. However, BA: IBA and BA: 2,4-D + CM combination were observed to be better in petiole explants as reflected by the biomass values.

Earlier study on in vitro propagation of Picrorhiza kurroa reveals that regeneration of shoot bud from ex vitro leaves on $\mathrm{Kn}$ $(3.48 \mu \mathrm{M})$ after 15 days of inoculation while, shoot bud primordial from callus was produced on TDZ $(0.5 \mu \mathrm{M})$ Patial et al., (2012). NAA 0.1 and $1.0 \mathrm{mg} / \mathrm{l}^{-1}$ alone in the medium or fortified with 0.01 and 1.0 and 1.0 $\mathrm{mg} / \mathrm{l}^{-1}$ BA resulted into callusing as well as higher proliferation rate of calli in Swertia pseudochinensis while, in Swertia japonica successful growth of calli was obtained with the addition of $1.0 \mathrm{mg} / \mathrm{l}^{-1} 2,4-\mathrm{D}$ or $1.0 \mathrm{mg} / \mathrm{l}^{-1}$ IAA or NAA using seedling root or hypocotyle as explants (Miura 1991). The variation in the concentration of cytokinin and auxin for callus induction in the present study may be due to explants used and physiological age of the explants. Physiological age of explants is an important factor determining the morphogenetic response (Ammirato 1996). In general explants derived from micropropagated shoots have an early and greater capacity for morphogenesis than tissues excised from field plants (George 1996). Maximum number of shoots (23.95 \pm 2.76) was produced after 90 days using BA $\left(1.5 \mathrm{mg} / \mathrm{l}^{-1}\right)$ and IBA $\left(1.0 \mathrm{mg} / \mathrm{l}^{-1}\right)$ combination (Plate 6 and 7 ). In the second set maximum shoots appeared in 1.5: $1.0 \mathrm{mg} / \mathrm{l}^{-1}$ concentration followed by $1.0: 0.5 \mathrm{mg} / \mathrm{l}^{-1}$ and 2.0: $1.5 \mathrm{mg} / \mathrm{l}^{-1}$ combination of BA and NAA at 90 days stage. Shoots were induced from callus on White's medium fortified with 1 $\mathrm{mg} / \mathrm{l}^{-1}$ BA and $2 \mathrm{~g} / \mathrm{l}^{-1}$ casein hydrolysate in Swertia pseudochinensis by Miura (1991). Root induction was studied in MS medium supplement with 0.5 to $1.5 \mathrm{mg} / \mathrm{l}^{-1}$ of auxin in separate sets of experiment in the well developed shoots that were transferred in the fresh medium for rooting purpose. Number of roots periodically recorded at the interval of 15 days (Plate 8).

Requirement of $0.5 \mathrm{mg} / \mathrm{l}^{-1}$ auxin in MS full for the development of higher number (9.33 \pm 1.13) of roots were recorded (Plate 9). However, slightly lesser number of roots $(8.12$ \pm 1.29 ) was noticed by using half of the MS medium with $1.0 \mathrm{mg} / \mathrm{l}^{-1}$ of auxin. Half strength B5 basal medium containing $1^{\mu x} \mathrm{~g} / 1^{-1}$ NAA has been reported to be suitable for root development in $S$. psedochinensis by Kitamura et al., (1987). 
Plate.1 Callus formation in leaf explants of Picrohiza kurroa with 2.5: $2.5 \mathrm{mgl}^{-1}$ of Kn and 2,4D. Plate.2 Callus formation in petiole explants of Picrohiza kurroa with 1.5: $2.0 \mathrm{mgl}^{-1}$ of Kn and 2,4-D + $15 \mathrm{mgl}^{-1}$ coconut milk. Plate.3 Callus formation in stem explants of Picrohiza kurroa with 2.5: $2.5 \mathrm{mgl}^{-1}$ of $\mathrm{Kn}$ and 2,4-D. Plate.4 and 5 Shoot bud differentiation from callus of Picrohiza kurroa with 1.5: $1.0 \mathrm{mgl}^{-1}$ of BA and IBA. Plate.6 and 7 Regenerated shoot from callus. Plate.8 and 9 Rooting response of Picrohiza kurroa with MS Full $+0.5 \mathrm{mgl}^{-1} \mathrm{IBA}$

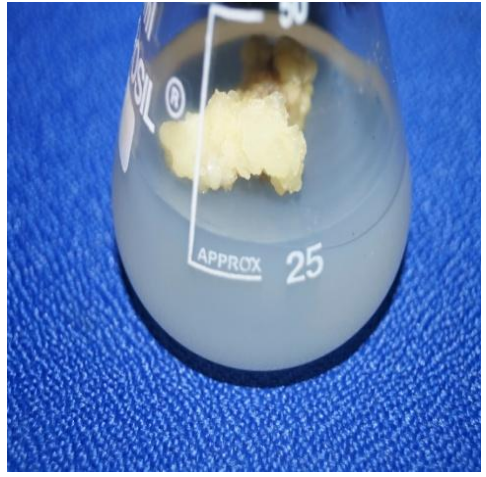

Plate 1

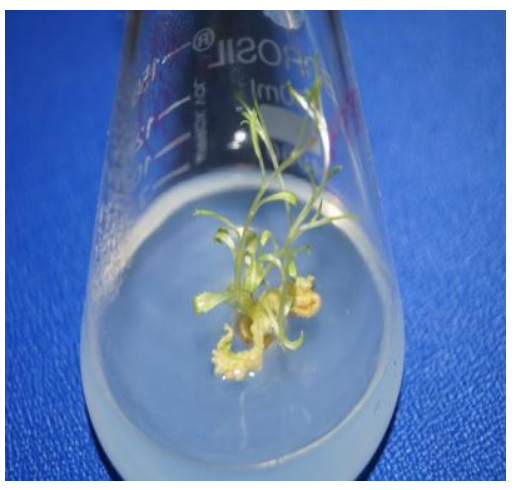

Plate 4

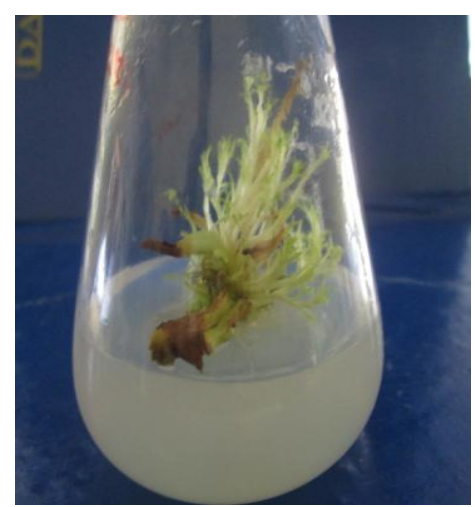

Plate 7

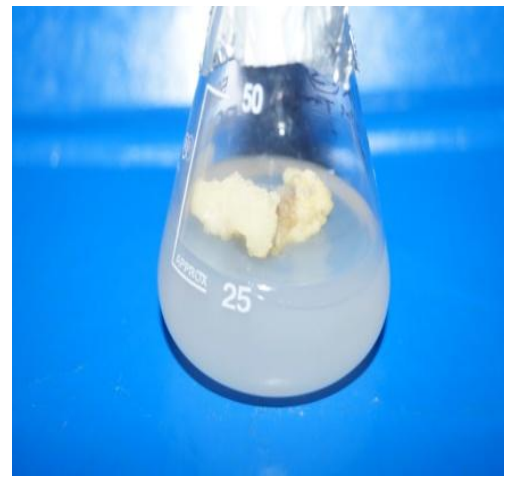

Plate 2

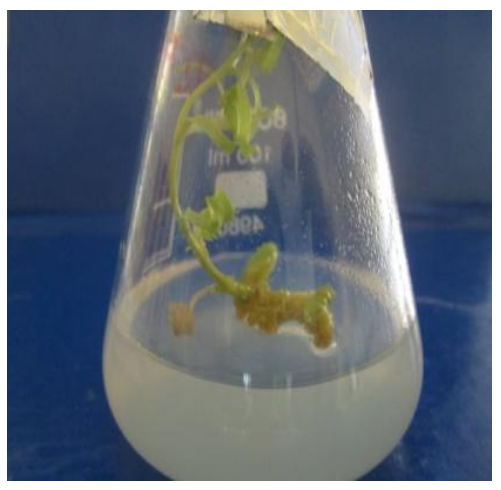

Plate 5

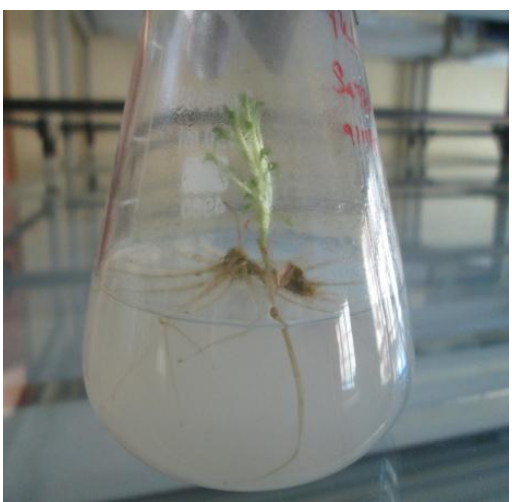

Plate 8

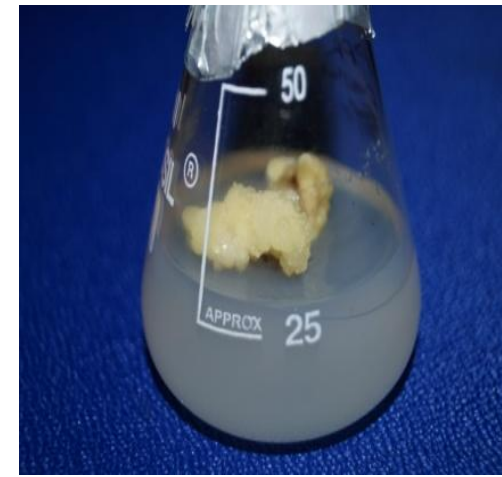

Plate 3

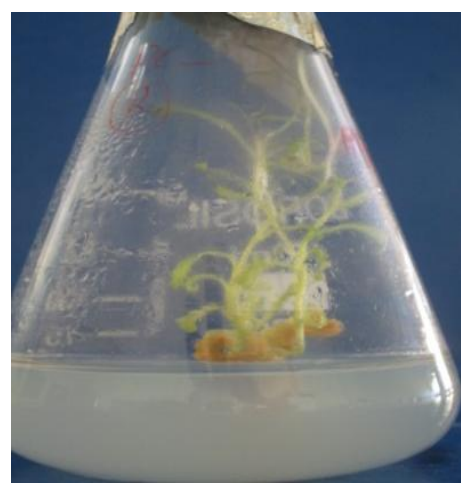

Plate 6

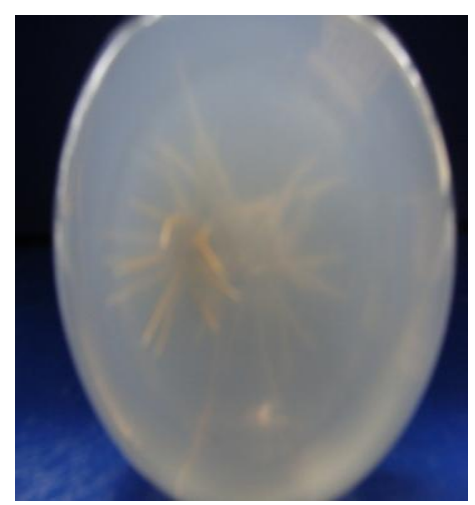

Plate 9 
Table.1 Maximum callus biomass* (mg.) of different explants of Picrohiza kurroa on MS media supplemented with cytokinin, Auxin and Coconut milk (CM) after 100 days of inoculation

\begin{tabular}{|c|c|c|c|c|}
\hline \multirow{3}{*}{$\begin{array}{l}\text { Cytokinin } \\
\left(\mathrm{mgl}^{-1}\right)\end{array}$} & \multirow{3}{*}{$\begin{array}{l}\text { Auxin } \\
\left(\mathrm{mgl}^{-1}\right)\end{array}$} & \multicolumn{3}{|c|}{ Explants } \\
\hline & & Leaf & Petiole & Stem \\
\hline & & Mean \pm SD & Mean \pm SD & Mean \pm SD \\
\hline $\mathrm{Kn}$ & $2,4-\mathrm{D} \backslash$ & & & \\
\hline 0 & 1.5 & - & - & $10.20 \pm$ \\
\hline 1.32 & & & & \\
\hline $\begin{array}{l}2.0 \\
0.95\end{array}$ & 2.5 & $11.36 \pm 1.57$ & - & $10.75 \pm$ \\
\hline 2.0 & 3.0 & $10.20 \pm 1.10$ & - & - \\
\hline 2.5 & 2.5 & $11.25 \pm 1.15$ & - & $10.97 \pm$ \\
\hline 1.10 & & & & \\
\hline 2.5 & 3.0 & $10.15 \pm 1.20$ & - & $11.12 \pm$ \\
\hline 3.0 & 2.5 & - & $10.90 \pm 0.90$ & $10.12 \pm$ \\
\hline 1.20 & & & & \\
\hline BA & IBA & & & \\
\hline 1.5 & 2.0 & $10.70 \pm 1.18$ & $11.27 \pm 1.17$ & $9.40 \pm 0.87$ \\
\hline 2.0 & 2.0 & $10.45 \pm 1.37$ & $10.98 \pm 1.40$ & $9.72 \pm 0.99$ \\
\hline BA & NAA & & & \\
\hline 1.5 & 1.5 & $10.08 \pm 0.90$ & - & - \\
\hline $\begin{array}{l}1.5 \\
1.22\end{array}$ & 2.0 & - & $9.20 \pm 0.88$ & $10.48 \pm$ \\
\hline 2.0 & 1.5 & $10.60 \pm 1.20$ & - & - \\
\hline 2.0 & 2.0 & - & $10.65 \pm 1.26$ & $9.82 \pm 1.07$ \\
\hline Kn & $2,4-D+15$ & & & \\
\hline 0.5 & 1.5 & $11.05 \pm 1.22$ & - & - \\
\hline 1.5 & 1.5 & - & $10.35 \pm 0.90$ & - \\
\hline 1.5 & 2.0 & $10.80 \pm 1.25$ & $10.62 \pm 1.10$ & - \\
\hline $\mathrm{BA}$ & $2,4-D+15$ & & & \\
\hline 1.0 & 1.5 & $10.60 \pm 1.44$ & $10.98 \pm 0.90$ & - \\
\hline 1.5 & 2.0 & $10.82 \pm 1.10$ & $10.40 \pm 1.07$ & - \\
\hline
\end{tabular}

*Biomass on fresh weight basis, - Poor response (very low biomass) hence not mentioned. 
Ten plantlets were kept at $25^{\circ} \mathrm{C}$ in growth chamber for studying the effect of temperature. $8-9$ plants died and in another experiment ten plantlets were kept at $18^{\circ} \mathrm{C}$ and $5-6$ plants survived. Three sets of 10 plantlets, each were kept at $18^{\circ} \mathrm{C}$ in Growth chamber. First and second set was MS medium and third set with water only. $5-6$ plants survived in first and second set while one plant survived in third set. The experiments were repeated thrice. Ten plantlets at two leaf stage were gradually exposed, initially for $1 \mathrm{hr}$. than 2, 3, $4 \mathrm{hrs}$. to shade and then gradually exposed to sun. Sixty per cent survival was noticed. These plants were then transferred to field condition. Higher percentage of survival could be achieved by keeping the plantlets under controlled conditions (Growth chamber) for a longer period by supplying adequate nutrients (held of quarter MS). MS medium irrigation with water only increased the mortality rate reflecting the requirement of nutrients at initial stages. It was important to maintain low temperature of $\left(18^{\circ}\right.$ to $\left.20^{\circ}\right)$ because at $25^{\circ} \pm 2^{\circ} \mathrm{C}$ most of the plantlets died.

Similar, finding has been reported for Valeriana wallichii (Mathur et al., 1987) and Centella asiatica (Banerjee et al., 1999). Field transfer trails made in the present study indicate that garden soil with organic compost potted plants kept in controlled environment for a longer duration, irrigation with half or quarter strength MS solution and gradual exposure to shade and sun are the desirable conditions to achieve high survival percentage for S. angustifolia.

$\mathrm{Kn}\left(2.0 \mathrm{mg} / \mathrm{l}^{-1}\right)$ and 2, 4-D (2.5 mg/ $\left./ \mathrm{l}^{-1}\right)$ combination is the best for callus proliferation while, 1.5 : $1.0 \mathrm{mg} / \mathrm{l}^{-1}$ of BA: NAA is most suitable for shooting and MS medium with $0.5 \mathrm{mg} / \mathrm{l}^{-1}$ of auxin for rooting. Keeping the plantlets under controlled conditions for longer period with supply of half or quarter
MS at low temperature $\left(18-20^{\circ} \mathrm{C}\right)$ resulted into the higher survival rate.

\section{Acknowledgement}

The authors wish to thank, our University Vice Chancellor Prof. Ajeet Kumar Karnatak and Prof. B.P. Nautiyal, Dean College of Horticulture, VCSG Uttarakhand University of Horticultural and Forestry Bharsar, Pauri Garhwal, Uttarakhand, for extending support.

\section{References}

Ammirato, P. V. 1986. Control and expression of morphogenesis in culture. Plant Tissue Culture and its Agricultural Applications (Eds: Withers LA and Aldrson. Pp. $23-45$, Butterworth. London.

Atal C.K., Sharma M. L., Kaul A. and Khajuria A. 1986. Immunomodulating agents of plant origin. I: preliminary screening. Journal of Ethbnopbarmacol., 18: 133-141.

Banerjee, S., Mehra, Z. and Kumar, S. 1999. In vitro multiplication of Centella asiatica a medicinal herb from leaf explants; Current Science 76 (2): 147 148.

George, E. F. 1996. Plant propagation by Tissue Culture, Part 2. Exegetics Ltd., Edignton, UK.

Hoareau, L., and DaSilva, E. 1999. Medicinal plants: a re-emerging health aid. Electro. J. Biotech. 2: 56 - 70.

Jia, Q., Hong, M.F. and Minter, D. 1999. Picroside; a novel iridoid from Picrorhiza kurroa. J. Natural Product; 62: 901-903.

Kitamura, Y., Nakano, M., Miura, H., and Sugil, M. 1987. Root cultures of Swertia pseudochinensis. Shoyakagaku Zasshi 41: 58 - 60.

Mathur, J., Ahuja, P. S., Mathur, A., Kukreja, A.K. and Shah, N. C. 1987. In vitro 
propogation of Valeriena wallishii. Planta Medica 39: 187 - 277, 1-3.

Miura, H. 1991. Swertia spp.: In vitro culture, regeneration and production of secondary metabolites. In: Bajaj Y.P.S., Medicinal and Aromatic Plants Vol. III. Eds: Biotechnology in Agricultural and Forestry, Heidelberg, Springer, pp. 451 -63 .

Murashige, T. and Skoog, F. 1962. A revised medium for rapid growth and bioassays with tobacco tissue culture, Physiologia Plantarum. 15: 473-497.

Nanda, L. and Ahuja, P. S. 1996. Plantlet regeneration from callus in Picrorhizza kurroa royal ex Benth-an endangered medicinal Plant. Plant Tissue Culture; 6(2): 127-134.

Nayar, M. P. and Shastry A. R. K. 1990. Red Data Book of Indian Plants. Vol. III (Botanical Survey of India, SI publication: Howrah, India.

Patial, V., Devi, K., Sharma, M., Bhattachary, A. and Ahuja, P. S. 2012. Propagation of Picrorhiza kurroa Royle ex Benth:
An important medicinal plant of Western Himalaya. Journal of Medicinal Plant Research Vol. 6 (34); 4848 - 4860.

Rastogii, A. K., Navdha, M., Gupta, N., Saksena, S., Goyal, N. and Roy, U. 1949. Protective effect of Picroliv from Picrorhiza kurro against Leishmania donovani infections in Mesocricetus auratus. Life Sciences; 63: 1823-1824.

Stuppner, H. and Wagner, H. 1989. New cucurbitacin glycosides from Picrorhiza kurroa. Planta Medicine. 1989; 55: 559-563.

Subedi, B. P. 2000. Plant profile: Kutki (Picrorhiza scrophulariifiora). Himalayan Bioresources,

Weinges, K., Kloss, P. and Henkels, W. D. 1972. Natural products from medicinal plants.. XVII. picroside -II, a new 6vanilloyl-catapol from Picrorhiza kurroa Royal and Benth. Justus Liebigs. Ann Chem. 759; 173-182. [Article in German].

\section{How to cite this article:}

Surjeet Singh Bisht and Sanjeev Verma. 2019. Standardization of in vitro Multiplication Protocol for Picrorhiza kurroa (Royle Ex. Benth). Int.J.Curr.Microbiol.App.Sci. 8(08): 20432049. doi: https://doi.org/10.20546/ijcmas.2019.808.238 